\title{
Psykoterapiens idéhistorie
}

Wolfgang Schmidbauer:

Die Geschichte der Psychotherapie. Von der Magie zur

Wissenschaft,

Herbig Verlagsbuchbandlung GmbH, 2012

444 sider, EUR 22,99.

Psykoterapien repræsenterer et stærkt underbelyst område inden for idé-, videns- og praksishistorie. Det skyldes med al sandsynlighed, at psykoterapien udgør en særdeles kompleks vidensbaseret mellemmenneskelig praksis, og at feltet rummer over 400 forskellige retninger. Samtidig kræver en anstændig belysning af området en kombination af en stærk historisk sans, filosofisk tæft og en indgående forståelse for den psykoterapeutiske praksisrationalitet.

Psykoterapiens idéhistorie repræsenterer desuden et særdeles kontroversielt område. Der eksisterer således en udbredt uenighed om, hvordan man overhovedet skal forstå psykoterapiens historiske fremkomst. Samtidig er der både udbredt uenighed om, hvordan man skal begribe psykoterapiens historiske relation til medicinen og psykoterapiens bredere sociale og kulturelle forankring. Den mest traditionelle og konventionelle historieskrivning daterer psykoterapiens oprindelse til Sigmund Freuds lancering af psykoanalysen i 1890erne. Det monumentale værk History of Psychotherapy fra American Psychological Association fra 2011 søger til gengæld psykoterapiens aner i de psykiatriske asylers moralske behandling i 1800-tallet. Henri Ellenbergers banebrydende værk The Discovery of the Unconscious fra 1970 sporede derimod den dynamiske psykoterapis forhistorie helt tilbage til oldtidens åndemaner- og exorcismepraksisser. Altså omfatter diskussionen et spænd på flere tusinde år.

Den anerkendte tyske psykoanalytiker Wolfgang Schmidbauer har udgivet en stærkt revideret udgave af sit tidligere værk Vom Umgang mit der Seele: Entstehung und Geschichte der Psychotherapie fra 1998. Det reviderede værk lægger sig umiddelbart i forlængelse af Ellenberger ved at trække psykoterapiens historie tilbage til oldtiden. Mens Ellenberger imidlertid kun viede en meget lille opmærksomhed til psykoterapiens tidlige historie, så giver Schmidbauers værk næsten halvdelen af plad- 
sen til den præ-moderne psykoterapi.

Schmidbauer indtager en særlig position i forhold til spørgsmålet om psykoterapiens relation til medicinen gennem sin kraftige betoning af psykoterapiens tidlige historie. Medicinen undergår således en gennemgribende historisk transformation fra lægekunst til socialmedicin og lægevidenskab ved overgangen til 1800-tallet. Derimod anskuer Schmidbauer psykoterapiens historie som en langvarig historie om rationalisering af helingspraksisser, der i mange henseender vedvarende har bevaret et nært slægtskab med shamanismen som sin arkaiske urtype. Schmidbauer bruger da også et helt kapitel i bogen til shamanismen som arkaisk psykoterapi og forsøger at aktualisere idéen. Samtidig trækker Schmidbauer et evolutionshistorisk spor fra magiske praksisser til psykoterapeutiske praksisser i en moderne forstand.

Schmidbauers stærke interesse for arkaiske urtyper og hans opslugthed af kulturelle riter og myter afslører et stærkt psykoanalytisk fundament. Bogen anviser således også en betragtelig mængde sideplads til psykoanalysens historiske fremkomst og forbilleder. Hele tre ud af tolv kapitler omhandler magnetisme, hypnose og suggestion efterfulgt af psykoanalysen omkring og efter Freud med en betragtelig særinteresse for psykoanalysens udvikling i de tysktalende lande.

Generelt viser Die Geschichte der Psychotherapie, hvordan tidligere samfund har indeholdt praksisser til at omgås såkaldte sjælelige forstyrrelser med. Disse praksisser har baseret sig på særlige idéer og fortolkninger, som har udgjort forskelligartede manifestationer af historiens kulturelle og sociale strømninger.

Schmidbauer påviser, hvordan fagområdet psykoterapi har udviklet sig til at blive et særdeles komplekst område, der er præget af indre spændinger og selvmodsigelser. Herunder gør Schmidbauer et nummer ud af at demonstrere, hvordan psykiske lidelser altid er socialt bestemte. Psykoterapiens hovedproblem er ifølge Schmidbauer, at den må forklare sig over for og i en vist forstand sætte sig op imod det samfund, hvori patienten er blevet sygt og skal være sundt igen. Samtidig har det samfund, som altså skaber psykiske lidelser vanskeligt ved at anerkende de mennesker, som bliver ramt af lidelserne. En manglende anerkendelse, som disse mennesker selv overtager og dermed har vi grunden til, at mange psykiske lidelser får et kropsligt udtryk, som f.eks. væksten af såkaldte funktionelle 
lidelser indikerer. I et vist omfang var det netop denne problemstilling, som den unge Michel Foucault tog fat på at undersøge i en række værker fra perioden mellem 1954 og 1962. Modsat Foucault er Schmidbauer imidlertid interesseret i en langt mere psykodynamisk tolkning af problemet. Samtidig påpeger Schmidbauer, at den moderne psykoterapi netop ikke finder nogen støtte i mere overordnede strukturer, der kan medvirke til at forandre de sociale betingelser for psykiske lidelser. Tværtimod har moderniteten medført en erodering af mere gennemgribende åndelige eller spirituelle strukturer i samfundet til fordel for magt-apparater, som beroer på en individ-orienteret cost-benefit tankegang. Den moderne psykoterapi udgør på den ene side et element $\mathrm{i}$ denne individualistiske cost-benefit tankegang, samtidig med, at dens hovedopgave så at sige er, at afbøde tankegangens konsekvenser og gøre den mere udholdelig. Som Schmidbauer påpeger, overbelaster det moderne samfund menneskets psyke, og det er nødvendigt at have blik for, hvordan den moderne verden modsiger vores følelsesliv.

I kølvandet på ungdomsoprøret forsøgte repræsentanter for det såkaldte frigørelsesprojekt i 1970erne og 1980erne at integrere psykoterapien i nye medicinske, pædagogiske og sociale sjælesorgsformer, der var knyttet til sociale reformer. Strømningen gav imidlertid også grobund for mere esoteriske retninger, som beskæftigede sig med astrologi, magiske sten og reinkarnation.

I de seneste årtier er det store frigørelsesprojekt især blevet udfordret af den biologiske psykiatris genkomst og den voldsomme udbredelse af moderne psykofarmaka samt populariseringen af de konventionelle psykiatriske diagnoser og kategorier. Samtidig har psykoterapien gennemgået en professionsmæssig opstramning og der er indført lovregulering af psykoterapeuter. Dette gælder imidlertid kun lande som Tyskland og England, mens Danmark endnu mangler regulering og autorisering på området.

Schmidbauer har bedrevet en glimrende indføring i psykoterapiens idéhistorie, der mest kan klandres for, at den har en overdreven fokusering på psykoanalysen i forhold til fagområdets moderne kompleksitet. Bogens indtryk bliver ind imellem skæmmet en smule af, at den ikke skrevet af en fagidéhistoriker. Til gengæld er den særdeles letlæselig. 